\title{
Between Competition and Cooperation: Financial Incumbents and Challengers in German Pension Politics
}

\author{
Nils Röper (D) \\ Postdoctoral Research Fellow, University of Konstanz, Germany \\ Corresponding author: Nils Röper, email: nils.roeper@gmail.com
}

\begin{abstract}
It has long been overlooked that factions of finance such as banks and insurers can have opposing policy interests. This paper is concerned with the preferences and strategies of private financial actors in the context of private prefunded pensions. To capture the "tug of war" among these actors, this paper identifies their different financial business models (insurance- and investment-orientation), political roles (financial incumbents and challengers), and levels at which infighting may occur (political and product-market level). For the German case, it shows that product-market competition among financial incumbents and challengers over retirement savings products only turned into competition politics during the 1990s, when shifting political winds provided an opening to insert path-shaping instruments in line with the program of finance capitalism. Financial actors' preferences are not a derivative of economic or functional incentives, but socially embedded in that they are crucially shaped by interactions with their competitors and the political environment. The analysis disentangles the complex web of competition, cooperation, and ownership among factions of finance and discerns their genuine preferences from those strategically adjusted to context. This sheds doubt on functionalist explanations of (pension) financialization and enhances our understanding of how financial actors form and pursue their preferences.
\end{abstract}

Keywords: financialization; welfare state; Germany; business power; pension politics

\section{Introduction}

Over the past decades, pension systems have become increasingly "financialized," leading to a growing share of old age income being dependent on capital markets. ${ }^{1}$ A key insight from recent literature is that not just the overall shift in relative weight from public to private and occupational forms of pension provision or from pay-as-you-go (PAYG) to prefunding is socially consequential but also, and especially, the design of prefunded pensions. Policies that liberalize investment regulations for prefunded pension schemes or subject pension providers to less comprehensive benefit guarantees, potentially expose pensioners to capital market risks more directly. ${ }^{2}$ This article is concerned with the preferences and strategies of private financial sector actors (PFSAs) with regards to private prefunded pensions.

It hardly needs emphasizing that PFSAs, such as insurers and banks, are crucial players in this context. They have become increasingly important administrators and providers of pension schemes and products. As such, they have vested interests in policies pertaining to prefunded pensions that boost their revenues rather than PAYG pensions, which they may consider as foregone profit. The politics of investment rules and benefit guarantees in prefunded pensions tend to have low public salience, and thus fall into the category of "subterranean"3 or "quiet politics." Here, producer groups in general

\footnotetext{
${ }^{1}$ Hassel et al. (2019).

${ }^{2}$ Naczyk and Hassel (2019).

${ }^{3}$ Hacker (2004).

${ }^{4}$ Culpepper (2010). Note that this is different from policies that aim at increasing prefunded pensions at the expense of (often public) PAYG pensions, which tend to involve public retrenchment and fall into the category of "noisy politics" (see Naczyk and Hassel, 2019).

(c) The Author(s), 2020. Published by Cambridge University Press on behalf of V.K. Aggarwal. This is an Open Access article, distributed under the terms of the Creative Commons Attribution licence (http://creativecommons.org/licenses/by/4.0/), which permits unrestricted re-use, distribution, and reproduction in any medium, provided the original work is properly cited.
} 
and organized business in particular-an important subgroup of which are PFSAs-tend to dominate. ${ }^{5}$ Yet the preferences and strategies of PFSAs and their ability to shape social policy outputs are surprisingly understudied. ${ }^{6}$

The pension-finance nexus offers a particularly rich laboratory to study cleavages within capital. Scholars of pension financialization have uncovered divergent preferences vis-à-vis occupational pensions between employers and PFSAs. ${ }^{7}$ Their call "to analyse the role of the financial industry," ${ }^{8}$ however, often exclusively refers to the insurance industry, and thus omits other factions of finance such as banks and investment companies. ${ }^{9}$ When referring to financial sector actors, scholars tend to consider the financial sector as a unitary actor or merely discuss the faction of finance they deem most relevant in a particular setting. This holistic or reductive perspective on the role of the financial sector is problematic. While all factions of finance generally share a preference for cutbacks in PAYG pensions and the expansion of prefunded pensions, they often compete in seeking (government) support for their respective retirement savings products and policies in line with their core business models. These policies and products differ in terms of the asset classes in which they invest and the risk-protection they offer, and thus their socioeconomic implications.

This paper zeroes in on the variegated preferences among PFSAs and the drivers of their strategic choices of action. Recognizing that PFSAs undergo complex preference formation processes and potentially have diverging interests, invites a more complex perspective on political conflicts and coalition building among PFSAs. Not just finance and its "powering" matters but how it constructs preferences and advances these across different institutional forums. Without taking these deeply political processes into account, we risk not fully understanding why PFSAs preferred a specific policy action in the first place and ultimately, how they got their way-or not. Broadly following the contention of economic actors' social embeddedness prevalent in economic sociology, I submit that preferences and strategic behavior of individual factions of finance are not purely a derivative of economic or functional incentives. ${ }^{10}$ Instead, their preference formation and political actions are crucially shaped by interactions with their competitors both at the political and product-market level, as well as the political environment. To make such a relational claim conceptually viable, this paper proposes analytical tools that systematize the pension-related business models of factions of finance and their internal hierarchy in a given context.

One may identify insurance- and investment-orientation as endpoints of the continuum of business models and political preferences pursued by PFSAs in the context of pension provision. This may refer to investment regulations for prefunded schemes and the payout of benefits. Investment-oriented factions champion defined contributions (DC) schemes and liberal investment ceilings that allow heavy investments in stocks-policy decisions that result in relatively higher degrees of financialization, as they mean more individualized risk and exposure to risky asset classes. In contrast, insurance-oriented factions favor defined benefits (DB) schemes and more conservative investment rules (see table 1 for an overview). ${ }^{11}$

Factions of finance with distinct business models can be expected to compete with one another at two levels: the product-market and the political level. At the product-market level, they constantly

\footnotetext{
${ }^{5}$ Mahoney (2007).

${ }^{6}$ Paster $(2015,27)$.

${ }^{7}$ Hacker (2002); Leimgruber (2008); Meyer and Bridgen (2012); Naczyk (2013).

${ }^{8}$ Naczyk $(2013,442)$.

${ }^{9}$ For exceptions, see Wehlau (2009); Naczyk and Hassel (2019); Röper (forthcoming).

${ }^{10}$ E.g., Beckert (2003); Woll (2008).

${ }^{11}$ Financialization may broadly be defined as "the web of interrelated processes [...] through which finance has extended its influence beyond the marketplace and into other realms of social life" (van der Zwan, 2014, 101). Pension financialization refers to various processes and outcomes, including "the rise of pre- funded defined-contribution plans managed by private financial services providers, [...] the growing dependence of pensioners' livelihoods on the performance of financial markets and the growing role of pension funds as providers of capital" (Hassel et al., 2019). This paper focuses on the implications of the preferences of factions of finance for the regulatory specifics of private pensions. For example, if investment-oriented factions who generally oppose insurance elements and payout guarantees had their way, individuals' pension benefits would depend more directly on capital market trends, and thus would be more financialized.
} 
Table 1: Ideal Types of Business Models and Political Preferences by PFSAs

\begin{tabular}{lll}
\hline & Insurance-Oriented PFSAs & Investment-Oriented PFSAs \\
\hline $\begin{array}{l}\text { Investment } \\
\text { regulations }\end{array}$ & $\begin{array}{c}\text { Ceilings limiting investments in riskier asset } \\
\text { classes }\end{array}$ & Flexibility to invest in stocks \\
\hline Payout of benefits & $\begin{array}{c}\text { Rigid annuitization and coverage of } \\
\text { biometric risks }\end{array}$ & $\begin{array}{c}\text { Defined contributions and flexible payout } \\
\text { options }\end{array}$ \\
\hline
\end{tabular}

compete over private old age savings by striving to appeal to customers and optimize their corporate marketing strategies. In contrast, "competition politics" 12 - conflicts over policies aiming to defend their turf or gain market share-are likely to be a less constant feature. Political agendas, after all, are finite and require shock events or marginally accumulated changes that are substantial enough to open up windows for new policy instruments and ideas. This "tug of war" among PFSAs at both levels is likely shaped by legacies of past decisions that have brought about a hierarchy among PFSAs, where some factions of finance are more dominant than others. Based on this notion of a financial sector that is diverse and hierarchical, this paper introduces the distinction of PFSAs into "financial incumbents" and "financial challengers." At the product-market level, incumbent dominance of certain factions of finance manifests itself in relatively higher revenues stemming from pension-related services. At the political level, incumbents can be expected to seek to preserve the status quo and their position of dominance, whereas challengers are change agents that strive to alter the status quo toward their preferences. ${ }^{13}$ Incumbents are likely to have a stronger influence over policies pertaining to prefunded pensions relative to other factions of finance (see table 2 for an overview).

To demonstrate the importance of distinguishing financial incumbents and challengers and considering their relations at the political and product-market level, this paper revisits the case of German pension politics. It examines the preferences and strategies vis-à-vis private pensions of the three main factions of German finance-banks, insurers, and investment companies-during the 1980s and the first half of the 1990s. Only in 1995 did financial challengers (banks and investment companies) begin to push for "financialized," equity-oriented, DC pension funds aiming for maximized yields and capital formation. Financial incumbents (insurers), in contrast, defended a definition of old age provision (and requisite versions of pension funds) that corresponded to a business model based on DB, payout guarantees, and insurance elements covering biometric risks and, thus, essentially, the status quo of the German private pension regime. ${ }^{14}$ I argue that both the absence of attempts to push for financialized pension funds in Germany prior to the mid-1990s and the, albeit largely unsuccessful, onset thereof in 1995 owe a great deal to the preferences, strategies, and power relations among the three main segments of finance.

The analysis disentangles the complex web of competition, cooperation, and ownership among factions of finance. It sheds doubt on the widely held premise of "coordinated" German inter-finance relations, as pension product-market competition was a permanent feature throughout the 1980s and 1990s when banks and insurers challenged each other's purviews. This in-depth account of product-market competition allows discerning PFSA's genuine preferences from those that have been strategically adjusted to context. While insurers opposed (relatively more) financialized pension funds, banks had but a second order preference for such constructs. Only investment companies had a first order preference for financialized pension funds, but were inhibited from acting on it before 1995. Not only was the political environment marked by distrust of finance capitalism and a perceived incommensurability of policy goals pertaining to old age provision and capital formation but investment companies were owned by banks and functioned as subcontractors for both banks and insurers. This constellation began to shift when policy ideas affirming the superiority of capital market-oriented practices were increasingly shared as the new interpretative framework among policymakers. When

\footnotetext{
${ }^{12}$ Mügge (2006).

${ }^{13}$ Callaghan (2018).

${ }^{14}$ Naczyk and Hassel (2019); Röper (forthcoming).
} 
Table 2: Levels of Competition Across German Financial Incumbents and Challengers

\begin{tabular}{lll}
\hline & Incumbents & Challengers \\
\hline Product-market level & $\begin{array}{c}\text { Competition over private old age savings } \\
\text { with higher market share }\end{array}$ & $\begin{array}{c}\text { Competition over private old age savings } \\
\text { with lower market share }\end{array}$ \\
\hline $\begin{array}{l}\text { Political level } \\
\text { Preserving the status quo and their position } \\
\text { of dominance }\end{array}$ & $\begin{array}{c}\text { Changing the status quo toward their } \\
\text { preferences }\end{array}$ \\
\hline Role & Insurers & Banks and investment companies \\
\hline
\end{tabular}

finance capitalism reached a political tipping point of dominance in $1995,{ }^{15}$ investment companies and banks sought to leverage this momentum toward financial liberalization in acting on their first and second order preferences for financialized pension funds, respectively. The move from product-market competition to financial competition politics was thus shaped more immediately by shifting political winds than functional changes.

The remainder of this paper is structured as follows. The second section situates its contributions in the literature. The third part sets up the research design for the subsequent case study. The final section concludes.

\section{The financial sector and the politics of pension financialization}

Welfare state research has been dominated by approaches of power resource theory focusing on the relative historical power of the political left and its alliances with the middle classes ${ }^{16}$ and historical institutionalism emphasizing that past policy decisions shape future trajectories in terms of institutions, dominant actors, and policy paradigms. ${ }^{17}$ These rich bodies of literatures have paid surprisingly scant attention to the links between the welfare state and adjacent domains, such as finance. ${ }^{18}$ Despite extensive literatures on financial system ${ }^{19}$ and pension system change, ${ }^{20}$ limited effort has been made to bridge these fields of research and capture the potential linkages between these central domains. Due to a compartmentalized perspective on policy domains and limited appreciation of interest groups beyond the corporatist core of employers and labor, welfare state research has paid little attention to the implications of financial system change in general and financial interest groups in particular.

The Varieties of Capitalism (VoC) framework, in contrast, centers on the linkages between institutional domains. It postulates that domains functionally cohere into complementary clusters of "coordinated" or "liberal" capitalist production types. ${ }^{21}$ Crucial efforts have been made to link this research agenda on modes of capitalist production to the worlds of welfare state regimes. ${ }^{22}$ Works in this vein explain the link between pension and financial systems largely in terms of static and functional elective affinities. For example, in "coordinated" political economies like Germany, bank-dominated financial systems tend to cluster with predominantly public PAYG pensions. ${ }^{23}$ Whilst insightful when seeking to understand the postwar consistency of this pension-finance nexus, these works reflect many of the well-rehearsed limitations of VoC in accounting for political change rather than continuity. ${ }^{24}$

More recently, scholars have begun to probe into the actual politics of the pension-finance nexus through the lens of financialization. The literature on pension financialization bifurcates into two

\footnotetext{
${ }^{15}$ Röper (2018).

${ }^{16}$ Esping-Andersen (1990).

${ }^{17}$ Pierson (1994).

${ }^{18}$ Streeck (2009); Carstensen and Röper (2019).

${ }^{19}$ E.g., Zysman (1983); Deeg (2005).

${ }^{20}$ E.g., Palier (2010); Ebbinghaus (2011).

${ }^{21}$ Hall and Soskice (2001).

${ }^{22}$ Ebbinghaus and Manow (2001).

${ }^{23}$ Jackson and Vitols (2001); Estévez-Abe (2001).

${ }^{24}$ Naczyk $(2016,206)$.
} 
main perspectives: Some consider the motives of policymakers and the state to make sense of pension financialization, ${ }^{25}$ others focus on the role of organized business interests. The business power literature increasingly rediscovers that "deep cleavages [...] divide [...] the business community," ${ }^{26}$ and has started to distinguish diverging preferences within finance and the interactions between PFSAs and business at large. ${ }^{27}$ This also holds true for the literature on the financialization of occupational pensions. ${ }^{28}$ These contributions, however, often equate the financial sector with the insurance industry, and thus pay scant attention to political contestation among segments of finance like banks and insurers. $^{29}$ Treating the financial industry actors like a unitary political actor amounts to a neglect of "competition politics" ${ }^{30}$ within finance for the domain of pensions. As Froud et al. $(2007,343)$ remind us: "financial institutions and actors are not coherent wholes with stable identities and shared interests."

Challenging the conventional wisdom that the financial sector be a monolithic group of actors that fervently pushes for (pension) financialization, this paper probes into variegated preferences among PFSAs and the drivers of their strategic choices of action. It introduces the notions of "incumbents" and "challengers" 31 among PFSAs. In alternative terminology, we may find protagonists, consenters, and antagonists of financialization among PFSAs, ${ }^{32}$ which would make this group of actors a key battleground contributing to the advancement and impediment of (pension) financialization.

While antagonism toward financialization from within capital has long been overlooked, recent literature has crucially begun to probe into the diverse set of preferences among factions of finance in the pension context. Naczyk and Hassel (2019) draw our attention to the heterogeneous preferences within German finance with regards to the "politics of private pension guarantees" and make important strides in explaining why the financialized pension fund challenge by banks and investment companies remained largely unsuccessful. The literature has yet to problematize, however, why prior to 1995 virtually no PFSA even proposed financialized pension funds and why challengers only began to do so in the mid-1990s. Analyses that allude to divergent preferences among factions of German finance only trace these back to the mid-1990s ${ }^{33}$ or even after the change in government in $1998 .{ }^{34}$ They fail to take into account the implications of prior developments on the level of product-market competition and do not attempt to disentangle the complex web of political and corporate links among segments of finance within an institutional arrangement marginally moving toward finance capitalism.

This paper extends work on financial diversity by probing into the genesis of preference formation among factions of finance prior to the mid-1990s. Instead of merely dismissing the VoC framework on conceptual grounds or using its core terminology, this paper explicitly engages with causal arguments deduced from the VoC framework. Highlighting the differences between product-market competition and financial competition politics, allows for a more dynamic understanding of what makes factions of finance act on what order of preference over time. Even under the "coordinated" German financial regime throughout the 1980s and 1990s, product-market competition was a constant feature. Rather than just statically taking stock of divergent interests among PFSAs, this paper also explores the question of what makes factions of finance change their strategy, even when genuine preferences remain unaltered. It shows that the nature of competition shifted from the product-market to the political level when political context permitted.

These findings confirm the economic sociologist's contention that the behavior of business actors is socially embedded. ${ }^{35}$ While factions of finance seek to maximize their economic self-interest, their

\footnotetext{
${ }^{25}$ E.g., Béland (2006); Trampusch (2018); Carstensen and Röper (2019).

${ }^{26}$ Hacker and Pierson $(2002,280)$.

${ }^{27}$ Mügge (2006); Pagliari and Young (2014); Young and Pagliari (2017).

${ }^{28}$ Hacker (2002); Leimgruber (2008); Meyer and Bridgen (2012); Naczyk (2013; 2016).

${ }^{29}$ For exceptions, see Oelschläger (2009); Wehlau (2009); Naczyk and Hassel (2019); Röper (forthcoming).

${ }^{30}$ Mügge (2006).

${ }^{31}$ Callaghan (2018).

${ }^{32}$ Korpi (2006).

${ }^{33}$ Oelschläger (2009); Naczyk and Hassel (2019).

${ }^{34}$ Wehlau (2009).

${ }^{35}$ Woll (2008).
} 
decisions are fundamentally relational and not purely derived from clearly given economic incentives. Instead, their decisions of when to act on which order of preference are shaped by interactions with other factions of finance and the political environment. That these interactions among factions of finance play out on different levels and in a context marked by hierarchy has important implications for historical institutionalist scholarship. The focus on financial challengers and financial incumbents may elucidate mechanisms of path dependence for pension financialization, where legacies of past policy decisions are said to stack the deck in favor of incumbents. ${ }^{36}$ Considering product-market competition in addition to competition politics may be a particularly promising research avenue when trying to capture marginal changes that potentially morph into substantial changes. ${ }^{37}$

\section{Research strategy}

These conceptual considerations give rise to important empirical questions about financial diversity and pension politics: What are the pension-related business models of factions of finance? Are these business models complementary or contrary? What are their genuine and strategic preferences? Under what circumstances does product-market competition turn into financial competition politics?

When identifying new causal mechanisms or variables, single case studies of extreme cases are particularly useful. ${ }^{38}$ There are significant and enduring cross-national variations in pension systems, e.g., with regards to the relative share of public and private forms of old age provision or prefunded and PAYG forms of financing pensions, but also in terms of how occupational, private, and public forms of prefunded pensions expose private households to financial market risks. ${ }^{39}$ Germany's postwar configurations represent archetypes among "nonliberal" political economies for both pension and financial systems. It can be considered an "extreme case" ${ }^{" 40}$ in terms of how change-averse ${ }^{41}$ and unfinancialized $^{42}$ it has been for the longest time and continues to be in many ways. ${ }^{43}$

This paper explores dynamics of market-product competition and competition politics and examines whether functional changes were crucial in shaping PFSA's behavior. An extremely unfinancialized case is apposite here. In extremely financialized cases, PFSAs may offer financialized pension products/schemes, but the regulatory environment also allows them to offer unfinancialized/insurancebased varieties. In contrast, in extremely unfinancialized contexts such as Germany, PFSAs are prohibited from (or are not eligible for subsidies when) offering financialized pension products/schemes, which makes for an interesting testing ground to examine interfinance competition. In Germany insurers dominate private pensions both in terms of market share and political clout, ensuring restrictive regulatory policies that favor protecting their purview. It is this extremeness with regards to the marked hierarchy at the product market and political level among factions of finance that makes the case of German private pensions particularly auspicious to examine the research questions posed herein.

To discern who wanted what and why, the analysis tracks the preferences and strategies of the three main factions of German finance throughout the 1980s and 1990s. One may distinguish genuine and strategic preferences. ${ }^{44}$ Genuine or first order preferences are actors' policy wishes independent of their political feasibility. While usually the territory of rational choice theorists, in the case at hand genuine preferences can be reasonably well deduced from PFSA's core business models and requisite expertise

\footnotetext{
${ }^{36}$ Naczyk (2013); van der Zwan (2017); Natali (2018).

${ }^{37}$ Streeck and Thelen (2005).

${ }^{38}$ George and Bennett $(2004,81)$; Gerring $(2007,104)$.

${ }^{39}$ Ebbinghaus (2011).

${ }^{40}$ Gerring (2007, 101ff.).

${ }^{41}$ Trampusch $(2009,30)$.

${ }^{42}$ van der Zwan $(2017,561)$.

${ }^{43}$ While nonstate prefunded pensions made up more than 50 percent of total retirement income in the United Kingdom in 2008 , it is less than 30 percent in Germany, with one of the lowest shares of equity in private pension funds among OECD countries (OECD 2009, 30-33). The private and occupational pillars of German old age provision are defined benefits pensions (van der Zwan, 2017; Wiß, 2019). Only in 2017 the occupational pension reform (Betriebsrentenstärkungsgesetz) for the first time introduced actual defined contribution schemes.

${ }^{44}$ E.g., Hacker and Pierson (2002); Korpi (2006).
} 
(e.g., insurance-based schemes for insurers and investment-oriented schemes for investment companies). Strategic or second order preferences refer to the most preferred option in light of the overall strategic setting, thus taking into account other actors' preferences and power base.

To empirically corroborate the argument developed above, I proceed in two steps. First, I establish that investment companies had a genuine preference for financialized pension. In contrast, banks had a strategic preference for such schemes and insurers no preference. To that end, I provide an overview of the political context of the German private pension regime and consider the business models and the web of competition and cooperation among the three segments of finance. Second, in 1995 investment companies and banks proposed financialized pension fund-type policy concepts for private and occupational pensions. By closely considering challengers' decision-making processes and weighing the evidence against functional arguments derived from the VoC framework as alternative explanations, I show that this "financialized challenge" crucially came about in reaction to a shifting political environment.

The analysis focuses on product-market competition and competition politics over private pensions among financial challengers and incumbents. Challengers encompass commercial banks (as represented by the BdB) and investment companies (BVI), incumbents in the insurance industry (GDV). This process tracing draws on a wide range of primary and secondary sources, including documentation from the Bundestag archives, newspaper archives, and twenty-three in-depth expert interviews with policymakers, academics, bureaucrats, and representatives of organized business.

\section{Finance vs. finance: The battle over the German old age nest egg}

\section{Political context: The private pension regime}

To grasp German interfinance competition over nonstate pensions and the obstacles of financialized pension funds during the 1980s and early 1990s, we first need to sketch the relevant political context. The seminal 1957 pension reform instigated a remarkable dissociation of pension politics into "separate worlds of old age provision." ${ }^{45}$ As the one-pillar approach meant that the public pension pillar alone should suffice to maintain one's standard of living throughout retirement, the purpose of occupational pension schemes altered from topping up meager public pensions to a tool of employee retention and motivation during times of full-employment. ${ }^{46}$ Wealth formation policymaking (Vermögenspolitik), often aiming at a higher share of "productive capital in the hands of employees," was also decoupled from the old age provision context. ${ }^{47}$ Company pensions and private wealth more generally became "de-socialpoliticized," ${ }^{48}$ and thus disjunctured from what was considered "pension politics" or the "pension system." This political pillarization of the three German pension pillars (public, private, and occupational) suggests that one needs to appreciate the evolution of politics pertaining to the nonpublic pillars in the context of the German postwar financial paradigm. ${ }^{49}$

Widely held until the 1990s as the ideal-typical, bank-based, and insider-oriented variety up until the 1990s, the German financial system constituted an institutional arrangement that shielded firms from short-term market pressures, and thus ensured "patient capital." ${ }^{\text {No }}$ Not least due to this conservative financial paradigm, policymakers across the political spectrum perceived policy goals pertaining to old age provision and capital formation as incommensurable: Equity-based products were considered overly speculative and thus inappropriate for private and occupational old age saving, while life insurances were deemed unsuitable to foster capital formation. ${ }^{51}$ As the favorable tax treatment of

\footnotetext{
${ }^{45}$ Berner $(2009,21)$.

${ }^{46}$ Hegelich $(2006,122)$.

${ }^{47}$ Dietrich $(1996,222-8)$.

${ }^{48}$ Berner (2009, 125).

${ }^{49}$ Carstensen and Röper (2019).

${ }^{50}$ Deeg (1999); Vitols (2004).

${ }^{51}$ Carstensen and Röper (2019).
} 
housing and life insurances was the "strongest pillar of German saving policy"52 and efforts to foster private capital formation through savings subsidies were markedly unsuccessful, ${ }^{53}$ the German private (old age) saving regime tended to favor the insurance sector. ${ }^{54}$ This is reflected in private savings pattern. Whereas in 1993 merely 12 percent of West Germans directly owned stocks, close to two thirds of households held a life insurance contract. ${ }^{55}$ Most company pension commitments were held as internal book reserves (Direktzusage) with such "organizationally embedded schemes" constituting a key source of market-independent liquidity ${ }^{56}$ and as such a core element of the patient capital configuration. Insurers were quasi-monopolist providers or administrators of all three external types of occupational pension schemes, which in 1993 made up more than 40 percent of assets covering company pensions. ${ }^{57}$ Insurers thus became incumbents in the political field of private and occupational pensions.

\section{Financial business models, competition, and cooperation}

Whereas a division of labor between banks and insurers prevailed throughout most of the 1970s, the principle of separation began to blur thereafter. In the aftermath of the 1974 recession, banks lost substantial market share in private wealth formation to the insurance industry. ${ }^{58}$ During a time when private household wealth became an ever more important source of funding for banks, ${ }^{59}$ insurers increased their share of private wealth from 13 percent in 1970 to more than 30 percent in the early 1990s. ${ }^{60}$ In the words of a life insurance executive, a "battle over the nest egg"61 ensued, which largely pertained to the old age nest egg, as most of the market share gained by insurers between the early 1960s and the early 1980 s can be attributed to life insurances. ${ }^{62}$

To regain some of the share lost to insurers, banks launched savings plans with insurance coverage (Sparplan mit Versicherungsschutz) in the early 1980s, a hybrid of bank and insurance products. ${ }^{63} \mathrm{~A}$ first attempt to do so by Commerzbank in 1981 failed. The bank had already announced the product and printed the requisite pamphlets. But in what one may refer to as a Deutschland AG-style "incumbent intervention," Paul Arno Bäumer, CEO of Allianz at the time (the largest German insurer held a stake of 15 percent in the then third largest German bank), proclaimed that old age provision needs to remain the prerogative of the insurance industry and prevented this in the eleventh hour. ${ }^{64}$ Two years later, Deutsche Bank did not get dissuaded and launched the first savings plans with insurance coverage.

It is not as if banks had not offered mixed products in cooperation with insurers in the past, but savings plans with insurance coverage were an immediate attack on life insurances-or "life insurance plagiarism," in the words of an insurance executive. ${ }^{65}$ Allianz CEO Wolfgang Schieren made no secret of his aversion to the new product: "I have told the board of Deutsche Bank that the banks are on their

\footnotetext{
${ }^{52}$ Börsch-Supan and Eymann $(2000,17)$. The 1975 tax reform stipulated that only two forms of savings be tax-exempt for the purpose of old age saving: building societies (Bausparkassen) and life insurances, if held for at least twelve years.

${ }^{53}$ Dietrich (2006).

${ }^{54}$ Vitols $(2003,104)$.

${ }^{55}$ Börsch-Supan and Eymann $(2000,2)$.

${ }^{56}$ Jackson and Vitols (2001).

${ }^{57}$ Nürk and Schrader (1995, i).

${ }^{58}$ Banks and insurers' business models have been interwoven since collaborating on sea loans in ancient times (Rudolph, 1987, 656). German banks founded most of the insurance companies in the early twentieth century so that most insurers were originally “insurance banks" (Kaven, 1987, 150). Refinancing banks accounted for almost one third of life insurers' overall portfolio in 1984 (Schwebler, 1984, 318). In addition, German insurers predominantly invested in fixed-income securities, which they bought through banks (Kratz, 1979, 474).

${ }^{59}$ Rudolph $(1987,657)$.

${ }^{60}$ Krupp $(1993,335)$.

${ }^{61}$ Die Zeit (1988).

${ }^{62}$ Wirtschaftswoche (1987).

${ }^{63}$ Stracke $(1988,590)$.

${ }^{64}$ Die Zeit (1988).

${ }^{65}$ Peiner (1991, 273).
} 
way to break certain rules (Ordnungsregeln), which simply exist in business, in this case the principle of separation. Back in the day one used to say: cobbler, stick to your trade."

These warnings notwithstanding, Deutsche Bank took further steps toward escalating the conflict with Allianz and the insurance industry at large. In 1984, Deutsche Bank still reassured their rivals that "[a] general inroad into the insurance business is not intended, especially as the insurance risk, as already practiced in connection with other bank services, is covered at insurance companies." 67 This promise proved ephemeral, for in 1989, Deutsche Bank founded its own life insurance.

Deutsche Bank went on to become a full-on bancassurance conglomerate. After founding a building society in 1987 and a life insurance firm two years later, Deutsche Bank in 1992 started expanding its stake in the insurer Deutscher Herold, which in 1995 merged with Deutsche's life insurance into Deutscher Herold Lebensversicherungs-AG der Deutschen Bank, the fifth largest German life insurer at the time. A Deutsche Bank board member bluntly rejected cooperative notions underlying Allfinanz-the mantra postulating that in order to stay competitive in retail finance, financial firms ought to offer the whole range of financial services-in submitting that the main reason for the founding and majority acquisition of life insurers "lies with the long-term market position of banks: cooperation solutions are not suited to counter the increasing shift in private wealth formation toward the insurance sector." ${ }^{68}$ The largest German bank understood the battle over the old age nest egg as a zerosum game of competition between banks and insurers.

Allianz in turn started in 1989 to cooperate with Dresdner bank, the second largest German bank at the time, in cross-selling each other's products and other services like special funds. In 1991, Allianz increased its stake in Dresdner Bank to 23 percent $^{69}$ and acquired it completely in 2001, after attempts to merge with Deutsche Bank and Commerzbank had failed. However, Allianz started to resemble a bank or rather an investment company much earlier. In 1985 the insurer restructured itself as a holding, which meant more maneuvering room in terms of investment activities and a first step toward becoming an asset manager, ${ }^{70}$ which eventually led to the insurer turning into one of the largest asset managers in the world. ${ }^{71}$ This is reflective of a larger trend beginning in the second half of the 1980s when German insurers started acquiring stakes in investment companies, founding them, or teaming up with partner banks in setting them up. ${ }^{72}$

The in-between position of investment companies further complicates this web of cooperation and competition among factions of German finance. Even though banks owned investment companies, their relationship was not unambiguously marked by mutual support. ${ }^{73}$ On the one hand, investment companies provided services beyond banks' expertise (e.g., annuities or automatic reinvestment), amounting to a collaborative division of labor. On the other hand, subsidiary investment companies absorbed liquidity that parent banks may well wanted for their balance sheets: "A conflict of interest between the investment industry and banks emerges whenever savings deposits are transformed into investment certificates, because: the more savings deposits, the higher potential lending." ${ }^{\prime 4}$ In practice, investment companies often had to subordinate their business interests to those of the parental banks. ${ }^{75}$

\footnotetext{
${ }^{66}$ Der Spiegel (1985).

${ }^{67}$ Deutsche Bank $(1984,46)$.

${ }^{68}$ Krupp $(1993,335)$.

${ }^{69}$ Der Spiegel (1991).

${ }^{70}$ Pohl $(2011,50)$.

${ }^{71}$ Warth $(2000,10)$.

${ }^{72}$ Peiner $(1991,272)$.

${ }^{73}$ While German banks are largely universal banks that can engage in a wide range of financial activities, the Investment Company Act defines investment companies as banks providing services such as asset management of both securities and properties (Fintelmann 1978, 258). For overviews of the relationship between banks and investment companies, see Baums (1995); Steenbock (1999, 188-95).

${ }^{74}$ Interview Laux; see also Fintelmann (1978, 258-9).

${ }^{75}$ Already in the late 1950 s, banks vehemently opposed policy initiatives toward what they derogatively referred to as a "shareholder democracy" (Dietrich 2006, 799-800). "As providers of deposit banking services, [universal banks] benefit through attracting more savings where small investors are discouraged from buying shares" (Callaghan 2018, 74; see also Fritsch
} 
At the same time, investment companies' business ties to insurers grew thicker throughout the 1980s. Insurers, for example, were by far the main buyers of so-called special funds (Spezialfonds). ${ }^{76}$ Also, the most successful example of Allfinanz cross-selling were maturity funds (Ablauffonds) that insurers sold as an interim investment when a life insurance contract expired. It hardly surprises that representatives of insurers and investment companies extolled maturity funds and Spezialfonds as testimony to the "cooperative relationship"77 between banks (by extension) and insurers. ${ }^{78}$ Traditionally, investment companies had played a passive role as subcontractors for both insurers and banks up until the early 1990s, while benefitting from the competition between banks and insurers: The ever more investment fund-like products that insurers and banks created in competing over private savings made investment companies the proverbial rejoicing third and the 1980s a "golden decade $^{\text {"79 }}$ for the investment industry.

Deutsche Bank and Allianz are widely considered to have formed the nucleus of the network of interlocking directorates and ownership ties that was the "Deutschland AG." 80 The escalating conflict between these two market leaders contradicts conceptions of noncompetitive relations for the realm or private (old age) savings and belies notions of informal market sharing or even a tacit agreement. Instead, what we see is a disparately complex evolution toward both increased competition and collaboration between banks and insurers. ${ }^{81}$ Commerzbank and Dresdner Bank, for example, sought to cooperate with insurers. ${ }^{82}$ Overall, however, the Allfinanz trend at least in the medium term meant intensified market competition between banks and insurers, according to the Federal Cartel Office. ${ }^{83}$ Insurers employed incumbent strategies to dissuade banks from further measures of intrusion into their purview by promoting cooperation over confrontation. Upon their public opposition to banks' savings plans with insurance coverage, insurers signaled a willingness to partner up with banks to provide them with the requisite insurance coverage. ${ }^{84}$ Life insurer association president Georg Schwebler warned in an article in the banking association's periodical that instead of creating new products, banks and insurers should focus on their shared potential while maintaining full product sovereignty for both parties in an "emancipated partnership," as competition could have "fatal consequences." 85

Based on this inventory of interfinance relations and the above overview of the wider political context, we can now establish the preferences and strategies of the three main factions of finance.

\section{Strategic and genuine preferences of factions of finance}

Banks were clearly aware of the importance of tax exemptions for the success of life insurances. ${ }^{86}$ In the context of the 1975 tax reform, the banking association unsuccessfully sought to obtain the same exemptions for long-term savings plans that invest in fixed-income securities and stocks. ${ }^{87}$ It was only in 1987 that banks undertook another (documented) unsuccessful attempt at seeking equal tax

1991, 16). In addition, banks' top management was traditionally recruited from corporate lending departments, and thus had little interest in and exposure to asset management (interviews Passow; Laux).

${ }^{76}$ Publikumsfonds are open to the general public, while Spezialfonds are reserved for institutional investors. In 1980 insurers accounted for almost half of all special funds volume (BVI 1981, 46), which further increased to about 75 percent in the late 1980s (Gode 1988, 430).

${ }^{77}$ Schwebler $(1987,442)$.

${ }^{78}$ See also BVI $(1987,63-4)$; Gode $(1988,431)$.

${ }^{79}$ BVI $(1990,74)$.

${ }^{80}$ Beyer $(2006,96)$.

${ }^{81}$ Kaven (1987).

${ }^{82}$ Die Zeit (1988). For an overview of collaborations, see Stracke (1988, 597-9); GDV $(1993,60)$.

${ }^{83}$ Remsperger (1989, 306).

${ }^{84}$ Wirtschaftswoche (1984).

${ }^{85}$ Schwebler (1986, 75-6).

${ }^{86}$ These privileges meant tremendous tax savings, for example, 1,275 DM on 15,000 DM invested in life insurances per annum (Der Spiegel 1974). For the tax treatment of life insurances, see Brunsbach and Lang (1998).

${ }^{87} \mathrm{BdB}(1974,25)$. 
privileges for their savings plans. ${ }^{88}$ Banks generally refrained from challenging life insurers' privileges publicly. Only in the context of the funding problems of the public pillar did the banking association even comment on pension politics for the first time in its annual reports. ${ }^{89}$ But despite the sentiment of a "pension crisis" and a widening coalition demanding multipillarization, banks made no meaningful attempts-neither publicly nor in elite policy discussions - to get involved in pension issues and did not participate in the 1989 Pension Reform Act. ${ }^{90}$ This absence contrasts with the salience of old age saving in terms of corporate competition at the time. ${ }^{91}$ Banks presumably saw limited chances in challenging insurers' incumbency in private pensions through political channels. At least on the political stage, private old age saving was the purview of life insurers. ${ }^{92}$ It was the "special lobbying success of the insurance sector" 93 that when it came to private pensions they "had a monopoly over the term." 94

It may be surprising that throughout the 1980s and early 1990s banks were silent on pension politics and did not voice any concrete demands in terms of three-pillar reforms, let alone develop policy proposals such as pension funds. Critics charge banks with a "lack of innovative ideas" 95 in terms of thinking beyond savings plans. ${ }^{96}$ The key question to ask, however, is whether banks actually had a preference for financialized pension funds (heavily invested in equity, DC, and no insurance elements) to challenge insurers. For example, when the banking association's periodical reported on the Employee Retirement Income Security Act of 1974-which crucially paved the way for US "pension fund capitalism" 17 no demands of similar tax provisions or even financialized, US-style pension funds in Germany were raised, even though the differences to German insurance-based occupational pension funds (Pensionskassen) were well understood. ${ }^{98}$ During the late 1980 s, a few banking practitioners began to point to the tremendous market potential that the introduction of pension funds would entail. ${ }^{99}$ But such voices proposing financialized policy concepts rather than market product innovations remained rare at this point and were not picked up at the organized level.

Banks did not have a first-order preference for US-style pension funds, but for more government support for their savings plans. ${ }^{100}$ Banks' business model was based on maturity transformation rather than annuity products. ${ }^{101}$ It was not necessarily for the lack of a window of opportunity or political clout that banks did not push for capital market-oriented pension schemes; it was testament to their genuine rather than strategic preference. One may also make the case that banks had limited interest in pushing for products that would mostly benefit investment companies. ${ }^{102}$

Investment companies, in contrast, had a genuine preference for pension funds. ${ }^{103}$ A 1984 BVI "special" entitled Tax Advantages of Old Age Provision with Investment in the US highlights that "[i]n terms of old age provision, German tax law has focused on life insurances. They receive far-

\footnotetext{
${ }^{88}$ Rudolph (1987, 657).

${ }^{89} \mathrm{BdB}(1987,13)$.

${ }^{90}$ Interviews: Laux; Dreßler; Lueg; Passow; Schwarz-Schilling; Rürup; von Rosen.

${ }^{91}$ Consider the topics of some of the seminars that Deutsche Bank employees took in preparation of selling life insurances: "changes in the age pyramid," "current and future situation of the public pension system," "company pensions," "necessity of private old age provision" (Bohm, 1990, 104-5). Dresdner Bank even began offering a consulting tool that allowed calculating individual "provision gap" based on expected benefits from public and occupational pensions (Stracke, 1988, 597).

${ }^{92}$ Stracke and Pohl $(1988,192)$.

${ }^{93}$ Interview: Leven.

${ }^{94}$ Die Zeit (1997).

${ }^{95}$ Interview Laux.

${ }^{96}$ Rudolph $(1987,658)$.

${ }^{97}$ McCarthy (2014).

${ }^{98}$ Die Bank (1977).

${ }^{99}$ Hauck (1987); von Rosen (1988).

${ }^{100}$ Interviews: Gerke; Bank.

${ }^{101}$ Zielke (2001).

${ }^{102}$ Interviews: Laux; Passow. Further substantiating this, banks later merely condoned investment companies' AS-funds in "silent acceptance" (Interview: Laux) - for example, when asked about the proper label for AS-funds, a BdB representative submitted to be "very emotionless" (BdB, 1997b) — and only became active protagonists once they had developed their own pension fund concept.

${ }^{103}$ Interviews: Laux; Passow.
} 
reaching tax advantages. In the United States, in contrast, there is a whole array of individual old age provision measures that are tax-wise on an equal footing." 104 This is emblematic of cautious challenges that do not make concrete demands but hint at the desirability of equal chances both in terms of tax privileges and company pensions. As subcontractors for both banks and insurers, investment companies did not challenge life insurers' tax privileges more overtly. While they advocated their own products as flexible alternatives to pure savings plans or life insurances to fill public pensions' "provision gaps," 105 investment companies veiled policy demands of equal tax treatment with references to other countries. Rather than fervently acting on their first order preference of equity-based pension schemes, investment companies refrained from challenging life insurers' tax privileges, presumably not least because their business ties grew thicker throughout the 1980s. When the BVI for the first time raised the detrimental effects of the German public PAYG pension system in its annual reports, they did not link this to their own products but to life insurances, which are the most important buyers of investment companies' special funds. ${ }^{106}$

We see product-market competition generating tremendous product convergence within the old path rather than financial competition politics with "path departing" policy solutions. In addition to banks offering insurance-like products, insurers themselves started offering savings plans with insurance coverage. ${ }^{107}$ Although unit-linked life insurances as hybrids of investment funds and insurance products had been on the German market since 1969, ${ }^{108}$ these new variations of life insurances are markers of convergence in that they "approximate to bank saving schemes very closely." 109 They represent "an increasing intertwining of long-term risk protection and capital formation on the one hand and flexible capital investment on the other," to the extent that one investment company CEO even saw reason to warn life insurers that these product innovations may jeopardize their tax exemption. ${ }^{110}$ In addition, investment companies began selling "investment savings plans" and "bond fund savings plan with insurance coverage." 111

The constellation of preferences and strategies among factions of finance traced in this section helps us understand why product-market competition prevailed over competition politics. Banks had but a second order preference for financialized pension funds, insurers sought to defend the status quo and the one faction with an interest in financialized pension funds-investment companies-was not only dependent on their parental banks but had also developed ever closer business ties to insurers. It is hardly surprising that nobody challenged incumbent insurers with financialized policy proposals, especially in light of a political environment marked by distrust of finance capitalism and a perceived incommensurability of old age provision and capital formation. The contested continuity delineated here, however, generated product convergence toward more financialized private pension products and shows that organized finance did not only begin to eye pension system change as a potential source of business by the mid 1990s, or that competition over private savings markedly intensified at that point, as often suggested. ${ }^{112}$ This begs the question of what had to change for banks and investment companies to move from product-market competition to competition politics.

\section{Financial competition politics and varieties of capitalism}

Upon the decision to form a Single European Market, the financial system increasingly became part of the German globalization-competitiveness debate in the second half of the 1980 s. $^{113}$ Rather than a "big

\footnotetext{
${ }^{104}$ BVI $(1984,49)$.

${ }^{105}$ E.g., BVI $(1983,30)$.

${ }^{106}$ BVI $(1988,47-50)$.

${ }^{107}$ Kürble and Hamann $(1985,373)$.

${ }^{108}$ Stracke and Pohl $(1988,196)$.

${ }^{109}$ Deutsche Bundesbank $(1987,18)$.

${ }^{110}$ Gode $(1988,434)$.

${ }^{111}$ BVI $(1985,29-33)$.

${ }^{112}$ E.g., Pieper $(2012,208)$.

${ }^{113}$ Beyer and Höpner $(2003,191)$.
} 
bang," however, marginal reorientations toward finance capitalism ensued. ${ }^{114}$ The political program of finance capitalism reached a tipping point of dominance by 1995 , which made for a political climate that was generally more receptive to financialized policy ideas. ${ }^{115}$ In this context investment companies and banks started to advocate for financialized pension funds in 1995. Whereas investment companies' Altersvorsoge Sondervermögen Fonds (AS-funds) were predominantly intended as pension fund constructs for the third pillar, Deutsche Bank's research arm demanded financialized occupational pension funds for the second pillar. ${ }^{116}$ This financialized challenge sparked a battle among factions of finance over defining "old age provision" and how it relates to the policy goal of deepening stock markets. ${ }^{117}$ Whereas the battle over the old age nest egg had previously taken the form of product-market competition over private pensions, the financialized pension fund challenge broke open financial competition politics over both private and occupational pensions. ${ }^{118}$

Undoubtedly a multitude of factors brought about this turning point. A single case study design makes it elusive to rule out all other forces and authoritatively establish causality over mere correlation between the decision to launch financialized pension funds and a changed political environment. Yet one can discuss alternative explanations to increase plausibility and establish that at least in relative terms, challengers' financialized pension thrust was more of a reaction to an altered political context than to functional incentives. In this context, it seems apposite to discuss the implications of the above findings for arguments deduced from the VoC framework.

VoC scholarship has laid much of the groundwork for analyzing the linkages between pension and financial systems in CPE. ${ }^{119}$ VoC scholars may argue that a deregulatory "unraveling" in finance has translated into functional pressures that brought about pension system change toward a new "liberal" equilibrium of institutional complementarity. Cohesion among financial actors may stem from a shared material interest in a functional response to an altered institutional context. Given the (de)regulatory changes and global competitive pressures it might have simply been in the interest of banks, insurers, and investment companies to push for more capital market-oriented private pension policy solutions. Only when the old mode of nonmarket coordination under the German model of finance began to erode, did we see the political battle over private and occupational pensions between factions of finance as of the mid-1990s that numerous authors have identified. In this view, only once German capital markets were substantially de- and re-regulated, were they ripe for pension multipillarization. Without rejecting these functionalist lines of argument altogether, findings from the above analysis point to their explanatory limitations and underscore the need for a more political perspective. ${ }^{120}$

The VoC framework has been subject to a wide range of criticism. One of the main lines of critique is that $\mathrm{VoC}$ is incapable of accounting for change rather than continuity. Institutional complementarity and reciprocally reinforcing strategies of policymakers and firms render the $\mathrm{VoC}$ approach without tools to explain institutional change. Based on the view that institutions constrain and enable actors to coordinate, only those changes matter that alter modes of interaction among actors. Hence, change in one institutional domain can solely occur in a coevolutionary fashion within the institutional arrangement of the political economy at large. Analytically speaking, only exogenous shocks may induce change in VoC, which then takes the form of exclusively positive feedback mechanisms toward a complementary equilibrium. ${ }^{121}$ The one endogenous source of fundamental institutional change that

\footnotetext{
${ }^{114}$ Jürgens et al. $(2000,67)$.

${ }^{115}$ Röper (2018).

${ }^{116}$ Nürk and Schrader (1995).

${ }^{117}$ Naczyk and Hassel (2019); Röper (forthcoming).

${ }^{118}$ It is this shift in the nature of the conflict among factions of finance enabled by an altered political context that explains why most studies take finance to only now gain an interest in the old age nest egg (e.g., Manow, 2001; Oelschläger, 2009; Wehlau, 2009; Hockerts, 2011; Pieper, 2012).

${ }^{119}$ Hall and Soskice (2001); Jackson and Vitols (2001); Estévez-Abe (2001); Vitols (2004).

${ }^{120}$ To be sure, for analytical purposes these arguments are derived from the original, "pure" version of VoC, which has been widely revised.

${ }^{121}$ Hay (2005); Streeck (2010).
} 
Hall and Soskice $(2001,64)$ concede- "[f]inancial deregulation could be the string that unravels coordinated market economies"-is a conjecture on which they barely elaborate.

In the case at hand an altered mode of coordination would entail a shift toward a market-based financial system and a pension system that is predominantly prefunded. This binary conception of change fits uneasily with the empirics, as both the German financial system ${ }^{122}$ and the pension system ${ }^{123}$ liberalized disparately. More interestingly, this paper puts into question the very premise that the German financial system was as coordinated as VoC scholars would have it. At the core of this conception of coordinated finance was a network of interlocking directorates and ownership ties. For the market of private savings products, scholars often implicitly assume informal coordination in adherence to the principle of separation between banks and insurers up until the mid-1990s. However, the above analysis, disentangling the complex web of political and corporate links among segments of finance prior to 1995 , indicates fierce competition over private old age saving beginning in the 1970s, which dispels notions of informal market sharing among the main factions of finance under the "Deutschland AG" regime. That these conflicts have largely been overlooked in the otherwise extensive literature on German finance may stem from oftentimes ideal-typified conceptions of informal coordination between banks and insurers.

Another way in which this paper challenges a VoC account of German pension financialization pertains to its rationalist ontological underpinnings. Due to game-theoretic assumptions about actor behavior and deterministic assumptions about institutional complementarities, actors merely function as "takers" of institutional logics in punctuated equilibria in the VoC universe. ${ }^{124}$ The absence of power, conflict, and sentience within the VoC framework has been criticized as hampering efforts to account for institutional change. ${ }^{125}$ Agency is essentially assumed away, as actors' behavior is the derivative of their institutional context. Institutions do not distribute power, but enable strategic coordination. ${ }^{126}$ Such "political fatalism"127 equalizes all interests with the common goal of economic efficiency. ${ }^{128}$

Now consider the case at hand against this backdrop. The genuine preferences of neither of the main factions of German finance changed throughout the 1980s and 1990s. Insurers always opposed financialized pension funds. By proposing AS-funds, investment companies acted on their longstanding genuine preference for financialized pension funds. The banking association soon threw its weight behind Deutsche Bank Research's 1995 proposal and in 1997 drafted a law proposal for financialized German occupational pension funds. ${ }^{129}$ Financial policymakers in fact asked for this BetriebsPensionsfonds proposal toward the end of the legislative process of the Third Financial Market Promotion Act. ${ }^{130}$ Banks' first order preference, however, continued to be tax privileges for their savings plans and one may consider "personal equity plans" as advocated by the Deutsche Aktieninstitut ${ }^{131}$ that banks could manage themselves without having to outsource them to investment companies as the highest ranking second order preference. ${ }^{132}$ But in light of shifting political winds, banks began to push for pension funds as an expression of their strategic preference.

A re-examination of investment companies' positioning further substantiates that it was in fact the prevalent conservative financial paradigm rather than functional obstacles that had guided their behavior. When the BVI began to consider the market potential that may result from future "provision gaps" in public pensions in the early 1980s, it exclusively referred to bond funds as a suitable product, given

\footnotetext{
${ }^{122}$ Deeg (2005); Röper (2018).

${ }^{123}$ Lamping and Rüb (2004).

${ }^{124}$ Note that already in Hall and Soskice's original formulation of the VoC framework these game-theoretic assumptions sat awkwardly with other more historical institutionalist notions about drivers of actors' behavior (Woll, 2008, 21-3).

${ }^{125}$ Korpi (2006).

${ }^{126}$ Howell $(2003,105)$.

${ }^{127}$ Hay $(2005,109)$.

${ }^{128}$ Streeck $(2010,24)$.

${ }^{129} \mathrm{BdB}(1997 \mathrm{a})$.

${ }^{130}$ Interview: Weber; F.A.Z. (1997).

${ }^{131}$ Fritsch (1991); DAI (1996).

${ }^{132}$ Interviews: Bank; Gerke; Laux.
} 


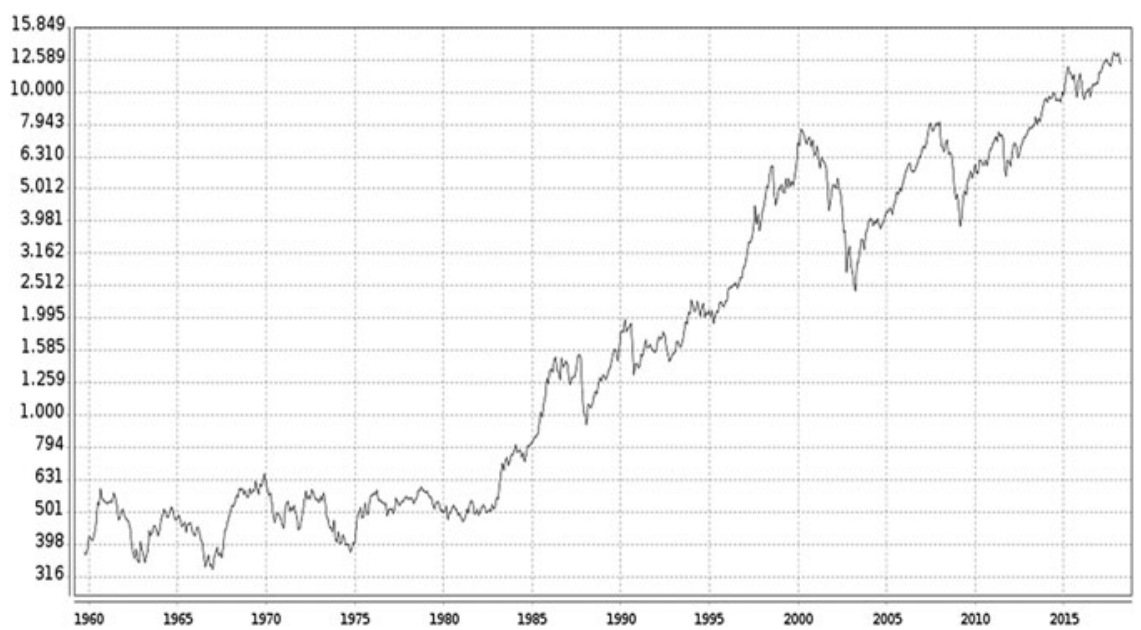

Figure 1: German Stocks (Dax) since 1959 Source: boerse.de

its security and predictability. ${ }^{133}$ This line of argument continued when investment companies introduced bond funds with insurance coverage: "Old age provision plays a prominent role in terms of motives to save among private households. Striving for maximum social security more than ever defines the general awareness." 134 Rather than for rates of return, investment funds were touted for their bank deposit-like transparency and liquidity, ${ }^{135}$ while the German reluctance to take more risk was lamented as a "psychoanalytical phenomenon." 136 Only after launching AS-funds, investment companies began to compare rates of return to competing products and the public pension system. ${ }^{137}$ They argued that over the long-term, AS-funds' "superior yields" vis-à-vis bond funds and life insurances would offset concerns about higher volatility and risk. ${ }^{138}$ Such notions of efficiency through cost averaging effects and compound interests marked a turning point. As one of the key actors involved at the time attests, the BVI only dared to advocate financialized products like AS-funds when it felt encouraged by finance capitalism's political momentum and chancellor Kohl's frequent call for more risk-taking in German politics at the time. ${ }^{139}$

A VoC explanation of the reorientations of financial sector actors could not accommodate that the first order preferences of all three main factions of the German financial sector did not meaningfully change during the 1980s and 1990s. Instead, their reorientations were predominantly strategic adjustments to an altered political context. Rather than deregulation having effected changes in institutional incentives that made it "rational" to reorient, it was financial liberalization altering the political context on the heels of marginal changes brought about by product-market competition over private pensions. In this sense of political competition, financial liberalization may pit factions of finance against one another.

From a functional perspective, one may also argue that PFSAs and financial policymakers began to favor investments in equity over bonds in the mid-1990s due to "favorable financial timing." 140 German stock markets, however, merely oscillated during the first half of the 1990s and only really 


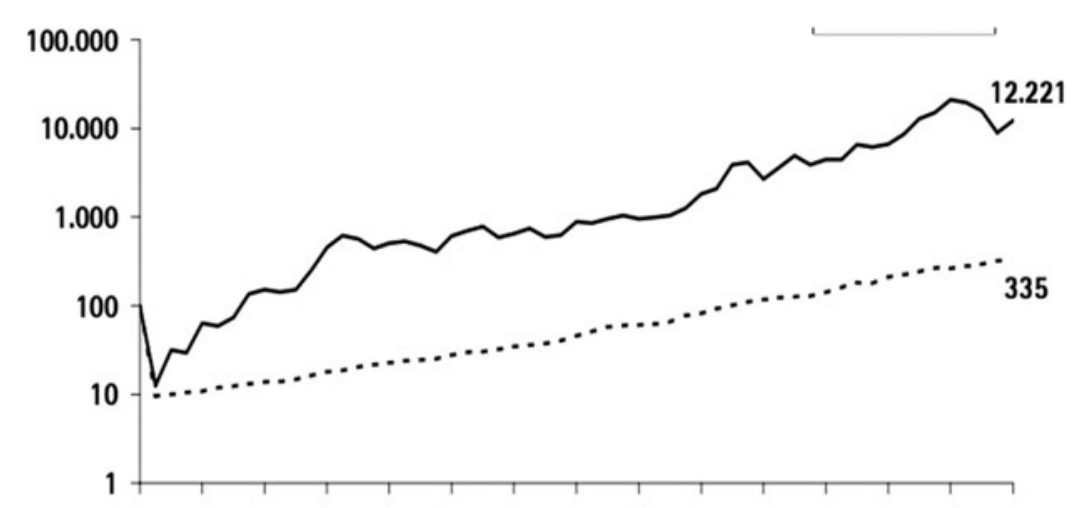

194719511955195919631967197119751979198319871991199519992003

stocks -- bonds

Figure 2: Returns on Stocks vs. Bonds (Germany, 1947-2003)

Source: DAI $(2004,96)$.

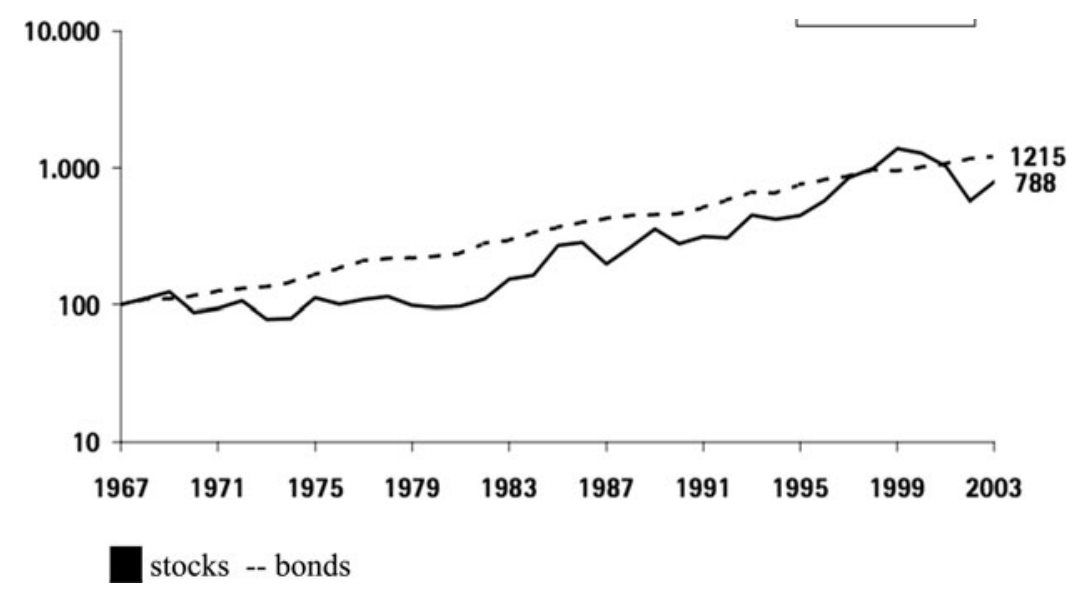

Figure 3: Returns on Stocks vs. Bonds (Germany, 1967-2003)

Source: DAI $(2004,99)$.

began to rally in 1996 (see figure 1). Even if the stock market development prior to 1995 had been more impressive, this would not help explain the shift in advocating equities over bonds, as the spread of yields between both forms of investment has not experienced substantive changes and, if at all, divergence set in after 1995 (see figures 2 and 3; for a survey of such comparisons, see DAI 2004). This is markedly different from other cases such as the United States, where stocks' rates of return have exponentially outpaced bonds since the 1940s (see figure 4). One may also assume that the technical infrastructure had yet to be developed to offer pension fund type products prior to the mid-1990s, but practitioners unequivocally deny this. ${ }^{141}$

This admittedly impressionistic consideration of $\mathrm{VoC}$ pension financialization arguments at least highlights their explanatory limitations. VoC's inability to accommodate non-hegemonic liberalization and the questionable premise of nonmarket coordinative finance in the case at hand already shed doubt on its ability to make sense of German pension financialization. That neither segment of finance altered their first order preferences during the 1980s and 1990s fundamentally contradicts VoC's

\footnotetext{
${ }^{141}$ Interviews: Laux; Passow.
} 


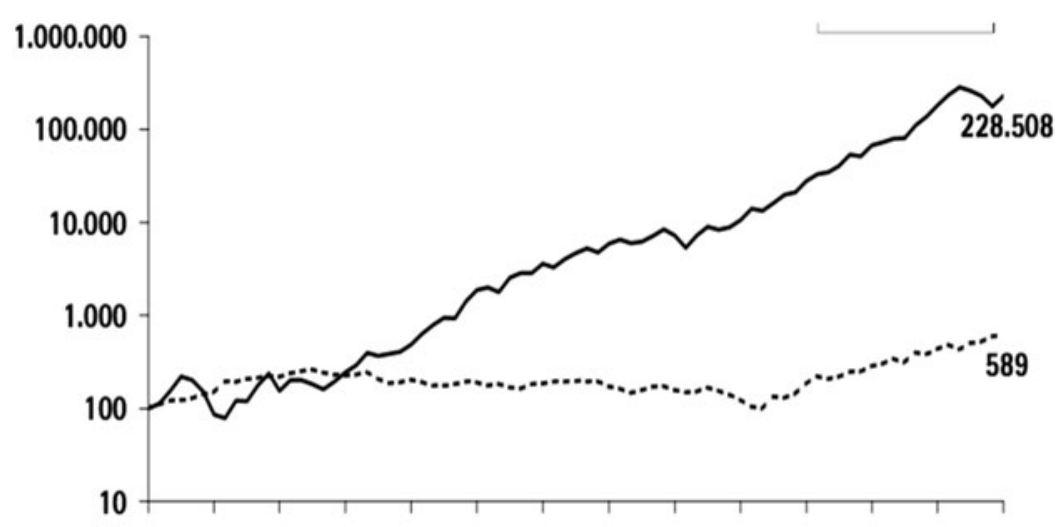

19251931193719431949195519611967197319791985199119972003

stocks -- bonds

Figure 4: Returns on Stocks vs. Bonds (US, 1947-2003)

Source: DAI (2004, 84).

assumption of rationalist actors' interests essentially aligning with institutional incentives. Changes in the political environment appear to have been causally consequential. Taken together, this suggests that deeply political processes bring about change at the pension-finance nexus and analyses need to be able to accommodate these.

\section{Conclusion}

The secular trend of pension financialization across developed political economies and the resulting "great risk shift" 142 make a more nuanced understanding of the political processes pertaining to design specificities of private and occupational pensions and their socio-economic implications imperative. While PFSAs such as banks and insurers play an ever more central role in pension provision, the literature tends to gloss over conflicts stemming from divergent social policy preferences within capital. Considering the financial sector as a monolithic political force blinds us to divergent preferences and political contestation. This paper has shown the preference formation and strategizing of factions of finance are fundamentally relational and political processes, and thus socially embedded. It has highlighted that capital-commanding profit-seekers may actually oppose elements of pension financialization, which may inspire revisiting some long-held conceptions of the roles played by capital and labor. This paper draws our attention to the different financial business models (insurance and investment orientation), political roles played by factions of finance (financial incumbents and financial challengers), and the levels at which financial infighting may occur (product-market competition and competition politics).

Beyond the realm of pension financialization, an enhanced understanding of the implications of coalition building and conflict within capital for political outcomes should illuminate broader questions about business power that are at the core of the comparative political economy literature. Further research could both delve deeper into the preferences and strategies PFSAs pursue and broaden the analytical lens. Financial competition politics in the policy field of pensions can be expected to play a role beyond the German case, not least because we see a tripartite division of the financial interest group landscape into insurers, banks and investment companies across developed political economies. The findings of this paper on the extreme German case should provide a useful starting point.

\footnotetext{
${ }^{142}$ Hacker (2006).
} 
Acknowledgments. The author would like to thank Cornel Ban, Kattalina Berriochoa, Marius Busemeyer, Martin B. Carstensen, Pepper Culpepper, Bernhard Ebbinghaus, Jane Gingrich, Daniel Kinderman, Marek Naczyk, Thomas Paster and David Rueda for their insightful comments on earlier versions of this paper.

Funding. Funded by the Deutsche Forschungsgemeinschaft (DFG - German Research Foundation) under Germany's Excellence Strategy - EXC-2035/1-390681379

\section{References}

Baums, T. 1995. Universal banks and investment companies in Germany. Working Paper, Institut für Handels- und Wirtschaftsrecht.

BdB. 1974. Jahresbericht 1973/74. Bundesverband deutscher Banken. Cologne.

BdB. 1987. Jahresbericht 1985/87. Bundesverband deutscher Banken. Cologne.

BdB. 1997a. Daten, Fakten, Argumente: Stärkung der privaten Altersvorsorge. Bundesverband deutscher Banken. Cologne.

BdB. 1997b. Statement by BdB representative during public hearing. Finanzausschuss, Bonn, 12.11.1997, BT-DS 510.

Beckert, J. 2003. "Economic sociology and embeddedness: how shall we conceptualize economic action?" Journal of Economic Issues 37 (3): 769-87.

Béland, D. 2006. "The politics of social learning: Finance, institutions, and pension reform in the United States and Canada." Governance 19 (4): 559-83.

Berner, F. 2009. Der hybride Sozialstaat: Die Neuordnung von öffentlich und privat in der sozialen Sicherung. Frankfurt am Main: Campus Verlag.

Beyer, J. 2006. Pfadabhängigkeit: Über institutionelle Kontinuität, anfällige Stabilität und fundamentalen Wandel. Frankfurt am Main: Campus Verlag.

Beyer, J., and M. Höpner. 2003. "The disintegration of organised capitalism: German corporate governance in the 1990s." West European Politics 26 (4): 179-98.

Bohm, R. 1990. "Lebensversicherungen im Bankvertrieb.” Die Bank 2 (90): 104-07.

Börsch-Supan, A., and A. Eymann. 2000. "Household Portfolios in Germany." Working Paper 00-15. https://ub-madoc.bib.unimannheim.de/2830/1/dp00_15.pdf.

Brunsbach, S., and O. Lang. 1998. “Tax Incentives and the Rate of Return on Saving through Life Insurance.” Jahrbücher für Nationalökonomie und Statistik 217 (2): 185-213.

BVI. 1981. Investment 81. Bundesverband Deutscher Investment-Gesellschaften. Frankfurt am Main.

BVI. 1983. Investment 83. Bundesverband Deutscher Investment-Gesellschaften. Frankfurt am Main.

BVI. 1984. Investment 84. Bundesverband Deutscher Investment-Gesellschaften. Frankfurt am Main.

BVI. 1985. Investment 85. Bundesverband Deutscher Investment-Gesellschaften. Frankfurt am Main.

BVI. 1987. Investment 87. Bundesverband Deutscher Investment-Gesellschaften. Frankfurt am Main.

BVI. 1988. Investment 88: Daten, Fakten, Entwicklungen. Bundesverband Deutscher Investment-Gesellschaften. Frankfurt am Main.

BVI. 1990. Investment 90: Daten, Fakten, Entwicklungen. Bundesverband Deutscher Investment-Gesellschaften. Frankfurt am Main.

BVI. 1994. Investment 94: Daten, Fakten, Entwicklungen. Bundesverband Deutscher Investment-Gesellschaften. Frankfurt am Main.

Callaghan, H. 2018. Contestants, Profiteers, and the Political Dynamics of Marketization: How Shareholders Gained Control Rights in Britain, Germany, and France. Oxford: Oxford University Press.

Carstensen, M. B., and N. Röper. 2019. "Invasion from within: Ideas, Power and the Transmission of Institutional Logics between Policy Domains." Comparative Political Studies 52 (9): 1328-63.

Culpepper, P. D. 2010. Quiet Politics and Business Power: Corporate Control in Europe and Japan. New York: Cambridge University Press.

DAI. 1996. Privater Aktiensparplan. Deutsche Aktieninstitut. Frankfurt am Main.

DAI. 2004.

Deeg, R. 1999. Finance Capitalism Unveiled: Banks and the German Political Economy. Ann Arbor, MI: University of Michigan Press.

Deeg, R. 2005. “Change from within: German and Italian finance in the 1990s." In Beyond Continuity: Institutional Change in Advanced Political Economies, edited by W. Streeck and K. Thelen, 169-202. Oxford: Oxford University Press.

Der Spiegel. 1974. "Steuerreform: Für viele wenig, für wenige mehr." 1 July 1974, 28-39.

Der Spiegel. 1985. "Wir denken über neue Produkte nach.” 7 January 1985, 52-60.

Der Spiegel. 1991. "Nur einer sagt, wo's langgeht. 5 August 1991, 84-86.

Deutsche Bank. 1984. Annual Report. http://www.bankgeschichte.de/en/docs/1984.pdf.

Deutsche Bundes. 1987. "Capital Formation and investment policy of insurance enterprises since 1979." Monthly Report of the Deutsche Bundesbank, January 1987, 17-31.

Die Bank. 1977. US-Pensionsfronds sind ein bedeutender Wirtschaftsfaktor. Die Bank 5 (77): 24-5. 
Dietrich, Y. 1996. Vom Miteigentum zur Vermögenspolitik: Die vermögenspolitischen Initiativen der CDU und die Entstehung der vermögenspolitischen Gesetzgebung des Bundes 1950-1961. Düsseldorf: Droste Vertrag.

Dietrich, Y. 2006. Vermögenspolitik. In 1958 - 1966 Budesrepublik Deutschland: Sozialpolitik im Zeichen des erreichten Wohlstands, edited by M. Ruck, 795-817. Baden-Baden: Nomos.

Die Zeit. 1988. "Hoffentlich 'Deutsche Bank' versichert!” 25 March 1988.

Die Zeit. 1997. "Kampf ums große Geld.” 25 April 1997.

Ebbinghaus, B., ed. 2011. The Varieties of Pension Governance: Pension Privatization in Europe. Oxford: Oxford University Press.

Ebbinghaus, B., and P. Manow, eds. 2001. Comparing Welfare Capitalism: Social policy and political economy in Europe, Japan and the USA. London: Routledge.

Esping-Andersen, G. 1990. The Three Worlds of Welfare Capitalism. Princeton, NJ: Princeton University Press.

Estévez-Abe, M. 2001. "The forgotten link: The financial regulation of Japanese pension funds in comparative perspective." In Comparing welfare capitalism: Social policy and political economy in Europe, Japan and the USA, edited B. Ebbinghaus and P. Manow, 190-214. London: Routledge.

F.A.Z. 1997. "Koalition denkt über echte Pensionsfonds nach." Frankfurter Allgemeine Zeitung, 13 November $1997,19$.

Fintelmann, E. 1978. Banken- Investment-Fonds: Arbeitsteilung oder Konkurrenz? Die Bank 6 (78): 258-61.

Fritsch, U. 1991. Steuerbegünstigte Aktiensparpläne für breite Bevölkerungskreise. Schriftenreihe des DAI. October.

Froud, J., A. Leaver, and K. Williams. 2007. "New actors in a financialised economy and the remaking of capitalism." New Political Economy 12 (3): 339-47.

GDV. 1993. Deutsche Versicherungswirtschaft Jahrbuch 1993. Gesamtverband der Deuschen Versicherungswirtschaft. Cologne.

George, A. L., and A. Bennett. 2005. Case Studies and Theory Development in the Social Sciences. Cambridge, MA: MIT Press.

Gerring, J. 2007. Case Study Research: Principles and Practices. Cambridge: Cambridge University Press.

Gode, W. 1988. "Die Investmentbranche wandelt sich.” Die Bank 8 (88): 430-37.

Hacker, J. S. 2002. The divided welfare state: The battle over public and private social benefits in the United States. Cambridge: Cambridge University Press.

Hacker, J. S. 2004. "Privatizing risk without privatizing the welfare state: The hidden politics of social policy retrenchment in the United States.” American Political Science Review 98 (2): 243-60.

Hacker, J. S. 2006. The Great Risk Shift. New York: Oxford University Press.

Hacker, J. S., and P. Pierson. 2002. "Business power and social policy: employers and the formation of the American welfare state." Politics \& Society 30 (2): 277-325.

Hall, P. A., and D. Soskice. 2001. "An Introduction to Varieties of Capitalism." In Varieties of Capitalism. The Institutional Foundations of Comparative Advantage, edited by P. A. Hall and D. Soskice 1-68. Oxford: Oxford University Press.

Hassel, A., M. Naczyk, and T. Wiß. 2019. "The political economy of pension financialisation: public policy responses to the crisis." Journal of European Public Policy 26 (4): 483-500.

Hauck, M. 1987. "Pensionskasse-Ein Instrument der Altersvorsorge. Der Kapitalmarkt im Lichte der Drei-Säulen-Theorie." Frankfurter Allgemeine Zeitung, 13 June 1987, 13.

Hay, C. 2005. "Two can play at that game...or can they? Varieties of capitalism, varieties of institutionalism." In Varieties of capitalism, varieties of approaches, edited by D. Coates 106-21. Basingstoke: Palgrave Macmillan.

Hegelich, S. 2006. Reformkorridore des deutschen Rentensystems. Wiesbaden: VS Verlag für Sozialwissenschaften.

Hockerts, H. G. 2011. Der deutsche Sozialstaat. Entfaltung und Gefährdung seit 1945. Göttingen: Vandenhoeck \& Ruprecht.

Howell, C. 2003. "Varieties of capitalism: and then there was one?" Comparative Politics 36 (1): 103-24.

Interview Bank. 2018. Author interview with economist Professor Matthias Bank, telephone, 11 October 2018.

Interview Dreßler. 2017. Author interview with former prominent SPD social policymaker Rudolf Dreßler, telephone, 5 December 2017.

Interview: Gerke. 2018. Author interview with economist Professor Wolfgang Gerke, telephone, 14 November 2018.

Interview: Hansen. 2017. Author interview with BDA director of 'Soziale Sicherung' Volker Hansen, Berlin, 23.10.2017.

Interview: Laux. 2017. Author interview with former BVI CEO Manfred Laux, Görlitz, 30 September 2017.

Interview: Leven. 2018. Author interview with deputy CEO Deutsches Aktieninstitut Franz-Josef Leven, Berlin, 9 July 2018.

Interview: Lueg. 2017. Author interview with GDV deputy director 'Alterssicherungspolitik' Thomas Lueg, Berlin, 14 December 2017.

Interview: Passow. 2017. Author Interview with former DIT CEO and BVI president Rolf Passow, Berlin, 6 October 2017.

Interview: Rürup. 2017. Author interview with economist Bert Rürup, telephone, 28 November 2017.

Interview: Schwarz-Schilling. 2018. Author Interview with former Telecommunications Minister Christian Schwarz-Schilling, Berlin, 17 January 2018.

Interview: von Rosen. 2017. Author interview with former CEO of the Arbeitsgemeinschaft der Deutschen Wertpapierbörsen, Deutsche Börse AG and Deutsches Aktieninstitut, Rüdiger von Rosen, Berlin, 6 December 2017.

Interview: Weber. 2017. Author interview with former BdB CEO Manfred Weber, Berlin, 20 November 2017.

Jackson, G., and S. Vitols. 2001. "Between financial commitment, market liquidity and corporate governance." In Comparing welfare capitalism: Social policy and political economy in Europe, Japan and the USA, edited by B. Ebbinghaus and Philip Manow, 171-89. London: Routledge.

Jürgens, U., K. Naumann, and J. Rupp. 2000. “Shareholder value in an adverse environment: the German case." Economy and Society 29 (1): 54-79. 
Kaven, J. P. 1987. "Banken und Versicherungen zwischen Konkurrenz und Kooperation.” Zeitschrift für das gesamte Kreditwese, 4: $148-54$.

Korpi, W. 2006. P"ower resources and employer-centered approaches in explanations of welfare states and varieties of capitalism: Protagonists, consenters, and antagonists." World politics 58 (2): 167-206.

Kratz, F. 1979. "Das Anlageverhalten von Versicherungsunternehmen.” Die Bank 10 (79): 472-75.

Krupp, G. 1993. "Bankstratgien im Versicherungsgeschäft.” Die Bank: 6 (93): 332-37.

Kürble, G., and T. Hamann. 1985. "Sparplan mit Versicherungsschutz und gemischte Lebensversicherung als vergleichbare Produkte.” Zeitschrift für die gesamte Versicherungswissenschaft, 74 (2-3): 371-402.

Lamping, W., and F. W. Rüb. 2004. 'From the Conservative Welfare State to an 'uncertain something else:' German pension politics in comparative perspective." Policy \& Politics 32 (2): 169-91.

Laux, M. 1996. “Pensions-Sondervermögen zur Abrundung des Altersvorsorgesystems.” Zeitschrift für das gesamte Kreditwesen 10 (96): $12-18$.

Leimgruber, M. 2008. Solidarity without the State? Business and the Shaping of the Swiss Welfare State, 1890-2000. Cambridge: Cambridge University Press.

Mahoney, C. 2007. "Lobbying success in the United States and the European Union." Journal of Public Policy 27 (1): 35-56.

Manow, P. 2001. "Globalization, Corporate Finance, and Coordinated Capitalism: Pension Finance in Germany and Japan." MPIfG Working Paper no. 01/5.

McCarthy, M. A. 2014. “Turning labor into capital: Pension funds and the corporate control of finance." Politics \& Society 42 (4): 455-87.

Meyer, T., and P. Bridgen. 2012. "Business, regulation and welfare politics in liberal capitalism.” Policy \& Politics 40 (3): 387-403.

Mügge, D. 2006. "Reordering the marketplace: competition politics in European finance." JCMS: Journal of Common Market Studies 44 (5): 991-1022.

Naczyk, M. 2013. "Agents of privatization? Business groups and the rise of pension funds in Continental Europe." Socio-Economic Review 11 (3): 441-69.

Naczyk, M. 2016. “Creating French-style pension funds: Business, labour and the battle over patient capital." Journal of European Social Policy 26 (3): 205-18.

Naczyk, M., and A. Hassel. 2019. "Insuring individuals... and politicians: financial services providers, stock market risk and the politics of private pension guarantees in Germany." Journal of European Public Policy 26 (4): 579-98.

Natali, D. 2018. “Occupational pensions in Europe: Trojan horse of financialization?” Social Policy \& Administration 52 (2): 449-62.

Nürk, B., and A. Schrader. 1995. Von der Pensionsrückstellung zum Pensionsfonds: Eine Chance für den deutschen Finanzmarkt. Deutsche Bank Research, Frankfurt am Main.

Oelschläger, A. 2009. “Vom 'Pensions-Sondervermögen' zur Riester-Rente-Einleitung des Paradigmenwechsels in der Alterssicherung unter der Regierung Kohl?” ZeS-Arbeitspapier, February 2009.

OECD 2009. "Pensions at a Glance 2009: Retirement-Income Systems in OECD Countries." Paris: Organisation for Economic Co-operation and Development.

Pagliari, S., and K. L. Young. 2014. "Leveraged interests: Financial industry power and the role of private sector coalitions." Review of International Political Economy 21 (3): 575-610.

Palier, B., ed. 2010. A long goodbye to Bismarck? The politics of welfare reform in continental Europe. Amsterdam: Amsterdam University Press.

Paster, T. 2015. "Bringing Power Back in: A Review of the Literature on the Role of Business in Welfare State Politics." MPIfG Discussion Paper 15/3.

Peiner, W. 1991. "Einflüsse in-und ausländischer Finanzdienstleister auf die Produktgestaltung in der Lebensversicherung." Zeitschrift für die gesamte Versicherungswissenschaft 80.2: 267-78.

Pieper, J. 2012. “Capitalists against capitalists: Widerstreitende Interessen von Unternehmen in der Sozialpolitik?" Sozialer Fortschritt 61 (9): 205-13.

Pierson, P. 1994. Dismantling the welfare state? Reagan, Thatcher and the politics of retrenchment. Cambridge: Cambridge University Press.

Pohl, H. 2011. Historische Skizzen zur Bankassekuranz. Stuttgart: Franz Steiner Verlag.

Remsperger, Hermann. 1989. "Erscheinungsformen, Ursachen und Implikationen von Allfinanz-Strategien.” Die Bank 6 (89): 299-309.

Röper, N. 2018. "German Finance Capitalism: The Paradigm Shift Underlying Financial Diversification." New Political Economy 23 (3): 366-90.

Röper, N. forthcoming. "Between Substantive and Symbolic Influence: Diffusion, Translation and Bricolage in German Pension Politics.” Review of International Political Economy. https://doi.org/10.1080/09692290.2020.1790405.

Rudolph, B. 1987. Sollten Banken am Versicherungsmarkt tätig sein? Die Bank 12 (87): 655-61.

Schwebler, R. 1984. “Kapitalanlagen der Lebensversicherer: Tendenzen und Perspektiven.” Die Bank 7 (84): 317-22.

Schwebler, R. 1986. "Chancen und Probleme im Beziehungsgeflecht von Banken und Versicherungen." Die Bank 2 (86): $72-6$.

Schwebler, R. 1987. "Neue Investitionsschwerpunkte der Versicherer." Die Bank 8 (87): 440-47.

Steenbock, A. 1999. Private Alterssicherung über den Kapitalmarkt. Wiesbaden: Deutscher Universitäts-Verlag.

Stracke, G. 1988. “Financial Services in Deutschland (V): Marktstrategien der Banken.” Die Bank 11 (88): 590-607. 
Stracke, G., and M. Pohl. 1988. "Financial Services in Deutschland (IV): Marktstrategien der Versicherer.” Die Bank 4 (88): 191-211.

Streeck, W. 2009. Re-forming capitalism: Institutional change in the German political economy. Oxford: Oxford University Press.

Streeck, W. 2010. "E Pluribus Unum? Varieties and Commonalities of Capitalism." MPIfG Discussion Paper 10/12.

Streeck, W., and K. Thelen. 2005. "Introduction: Institutional Change in Advanced Political Economies." In Beyond Continuity: Institutional Change in Advanced Political Economies, edited by W. Streeck and K. Thelen, 1-39. Oxford: Oxford University Press.

Trampusch, C. 2009. Der erschöpfte Sozialstaat: Transformation eines Politikfeldes. Frankfurt am Main: Campus Verlag.

Trampusch, C. 2018. "A state-centred explanation of the finance-pension nexus: New Zealand's pension reforms as a typical case.” Social Policy \& Administration 52 (1): 343-64.

van der Zwan, N. 2014. "Making sense of financialization." Socio-economic review 12 (1): 99-129.

van der Zwan, N. 2017. "Financialisation and the pension system: lessons from the United States and the Netherlands." Journal of Modern European History 15 (4): 554-84.

Vitols, S. 2003. "Varieties of Capitalism and Pension Reform: Will the 'Riester-Rente' Transform the German Coordinated Market Economy?" Focus on Austria 2: 102-8.

Vitols, S. 2004. "Changes in Germany's Bank-Based Financial System: A Varieties of Capitalism Perspective." Discussion Paper SP II 03, WZB Berlin.

von Rosen, R. 1988. "Pensionsfonds stärken den deutschen Kapitalmarkt.” Frankfurter Allgemeine Zeitung, 8 July $1988,14$.

Warth, W. 2000. "Bancassurance im Spannungsfeld zwischen Kooperation und Konkurrenz." Die Bank 1: 8-11.

Wehlau, D. 2009. Lobbyismus und Rentenreform. Der Einfluss der Finanzdienstleistungs-branche auf die Teil-Privatisierung der Alterssicherung. Wiesbaden: Verlag für Sozialwissenschaften.

Wirtschaftswoche. 1984. "Sparpläne mit Versicherungsschutz: Vom Kampf zum Kartell." 19 October 1984, 108.

Wirtschaftswoche. 1987. "Kampf ums Sparschwein.” 20 March 1987, 54.

Wiß, T. 2019. "Reinforcement of pension financialisation as a response to financial crises in Germany, the Netherlands and the United Kingdom." Journal of European Public Policy 26 (4): 501-20.

Woll, C. 2008. Firm interests: How governments shape business lobbying on global trade. Ithica, NY: Cornell University Press.

Young, K., and S. Pagliari. 2017. "Capital united? Business unity in regulatory politics and the special place of finance." Regulation \& Governance 11 (1) 3-23.

Zielke, Carsten. 2001. "Rentenreform = Bankassekuranz." Versicherungswirtschaft 54 (4): 1-8.

Zysman, J. 1983. Government, Markets and Growth: Financial Systems and the Politics of Industrial Change. Ithaca, NY: Cornell University Press.

Cite this article: Röper N (2021). Between Competition and Cooperation: Financial Incumbents and Challengers in German Pension Politics. Business and Politics 23, 243-263. https://doi.org/10.1017/bap.2020.13 